\title{
Epidemiological study on the prevalence of cystitis in women in the Voronezh region of Russia
}

\author{
Apolikhin $\mathrm{OI}^{1}$, Sivkov $\mathrm{AV}^{1}$, Naber $\mathrm{K}^{2}$, Wagenlehner $\mathrm{F}^{3}$, Perepanova TS ${ }^{1}$, Yu PM${ }^{1 *}$, Voitko DA ${ }^{1}$, Zolotukhin $\mathrm{OV}^{4}$, Nazarenko DG ${ }^{5}$ and \\ Shaderkin IAs ${ }^{6,7}$ \\ ${ }^{1}$ N. Lopatkin S.R, Institute of Urology and interventional radiology-branch of FGBU “National Medical Research \\ ${ }^{2}$ Centre of Radiology Ministry of Health Care of Russian Federation, Russia \\ ${ }^{3}$ Department of Urology, Technical University of Munich, Germany \\ ${ }^{4}$ Klinik und Poliklinik für Urologie, Kinderurologie und Andrologie, Germany \\ ${ }^{5}$ Voronezh Regional clinical hospital No. 1, Russia \\ ${ }^{6}$ Bobrov district hospital, Russia \\ ${ }^{7}$ Federal State Autonomous Educational Institution of Higher Education I.M. Sechenov First Moscow State Medical University of the Ministry of Health of the \\ Russian Federation (Sechenov University), Russia
}

\begin{abstract}
Introduction: The article presents the results of an epidemiological study on the prevalence of cystitis and risk factors for cystitis in women in the Bobrovsky district of the Voronezh region of Russia. Materials and methods: In 2018-2020 yy women aged 18 to 80 years were surveyed. A total of 1014 women were interviewed, of which 551 women of fertile age, and 463 women of postmenopausal age. In each group, we examined the effect of risk factors on recurrence UTI). Results: of the 1014 surveyed women, 155 (15.3\% of all women surveyed) had risk factors according to the ORENUC classification. The largest number of risk factors was observed in postmenopausal women $(\mathrm{p}<0.05)$. Lack of sex and having one sexual partner were not risk factors for cystitis recurrence ( $\mathrm{p}>0.05)$. A history of cystitis is associated with impaired gastrointestinal function $(\mathrm{p}<0.05)$. Conclusions: Our study confirms risk factors for recurrent cystitis in previously published studies. In addition, we found that the prevalence of cystitis in the Bobrovsky district of the Voronezh region of Russia, by interviewing women, is about $3.2 \%$, while 10 times less women seek medical help.
\end{abstract}

\section{Introduction}

Urinary tract infections (UTIs) are the most common bacterial infections, however, epidemiological data on the prevalence of cystitis differ. According to Griebling TL and Foxman B. about 11 million cases of UTI per year are described in the United States with estimated treatment costs of about 5 billion US dollars [1,2]. Other sources report somewhat different data: in the US, UTIs are responsible for 7 million medical visits a year, including 2 million for cystitis alone, with a total estimated cost of $\$ 3.5$ billion [3]. In Europe, patients with UTIs visit the doctor 3 times/year, costing an estimated $€ 1.5$ billion/ year $[3,4]$.

Cystitis takes up about $90 \%$ of all UTIs and recurs within $20-30 \%$ of women within 3-4 months, which leads to an increased consumption of antibiotics and a deterioration in the quality of life [3]. Cystitis accounts for $0.9 \%$ of all ambulatory visits in the United States [2].

In a primary care setting, $53 \%$ of women above the age 55 years and $36 \%$ of younger women report a recurrence within 1 year [5]. Women with all types of UTI reported 6.1 symptom days, 2.4 restricted-activity days, 1.6 office visits and laboratory tests, and US\$62 were spent for treatment of UTI, based on prices of a subsidized student health service [6].

A mean of 3 days per year of sick leave are due to UTIs in Europe [4]. 1 in 2 women of all ages will experience at least one episode of cystitis during their lifetime and recurs within $20-30 \%$ of women within 3-4 months, which leads to an increased consumption of antibiotics and a deterioration in the quality of life $[7,8] .42 .4 \%$ of the women were found to have suffered from recurrent UTIs for more than 10 years, while $23.2 \%$ had already suffered for more than 20 years [4]. UTIs are 50 times more common in premenopausal women than in men [3].

In Russia, there are 26-36 million cases of cystitis per year. During their life, $20-25 \%$ of women suffer acute cystitis, while every third woman has a recurrence within a year, and in $10 \%$ it turns into a chronic recurrent form. $[9,10]$. According to Laurent et al. by the age of 18-20, every fifth woman suffers from cystitis; by the age of 25 , at least one episode of urinary tract infection occurs in every third; among women 18-40 years old, from 500 to 700 people per thousand of the population suffer from cystitis [11].

The need for accurate diagnosis of infectious and inflammatory diseases of the urinary tract, in particular, cystitis, is of great importance for both patients and the community as a whole. Patients with recurrent cystitis widely use antibacterial prophylaxis for recurrent infections,

${ }^{\star}$ Correspondence to: Prosyannikov M. Yu, N. Lopatkin S.R, Institute of Urology and interventional radiology-branch of FGBU "National Medical Research Centre of Radiology Ministry of Health Care of Russian Federation, Moscow, Russia; E-mail: prosyannikov@gmail.com

Key words: cystitis, recurrence cystitis, risk factors for recurrence cystitis, ORENUC Received: February 19, 2021; Accepted: April 08, 2021; Published: April 15, 2021 
which leads to an increase in antibiotic resistance of uropathogens and the emergence of multi-drug resistant strains of microorganisms.

It is known that age-related risk factors are of great importance in women with recurrent cystitis. So, in young women of reproductive age in premenopause, factors such as sexual intercourse, use of contraceptives (spermicides, diaphragms) or change of sexual partner are of great importance for recurrent cystitis. Whereas, in postmenopausal women, estrogen deficiency most often leads to atrophy of both vaginal epithelium and urothelium with a decrease in the protective function of mucosal immunity. Age-related prolapse of organs leading to cystocele and residual urine is also a risk factor for the development of cystitis. Factors such as previous surgeries with bladder catheterization and age-related deterioration in organ function have also been noted, especially in older women in nursing homes [12].

Risk factors for recurrence of uncomplicated cystitis in adult women also include those who had UTI in childhood and genetic factors such as Toll-like receptor polymorphism and the presence of UTI in the mother $[13,14]$.

Cai et al. studied different risk factors on the rate of cystitis recurrence: age; marital status; the number of intercourse per week; use of contraceptives; smoking; alcohol and water consumption; asymptomatic bacteriuria treatment for the previous year; response to oral therapy; taking food supplements (cranberries); bowel function; type of pathogen isolated (Gram $+/-$ ); number of UTI exacerbations in the previous 12 months; number of sexual partners in the previous year; hormonal status. Multivariate analysis among the risk factors for the development of recurrent cystitis showed that the antibacterial treatment of asymptomatic bacteriuria in the interrecurrent period in patients with recurrent cystitis was of greatest importance, as well as bowel function (constipation); the number of cystitis exacerbations in the last 12 months (more than 3); the number of sexual partners (more than 2) and hormonal status (postmenopause) $[15,16]$

Thus, the need to study risk factors for the development of recurrence of bacterial cystitis is of great importance in order to formulate program measures for prevention and treatment. As part of this, taking into account the experience of the Research Institute of Urology and Interventional Radiology named after V.I. N.A., Lopatkina - a branch of the Federal State Budgetary Institution "National Medical Research Center of Radiology" of the Ministry of Health of Russia for the implementation of studies aimed at identifying risk factors for urological diseases [17-19]. With the assistance of the Bobrovsky District Administration of the Voronezh Region in 2019-2020 an epidemiological, population-based study was conducted to identify the frequency of cystitis in women and determine its risk factors.

\section{Materials and methods}

The study was carried out in the Bobrovsky District of the Voronezh Region of the Russian Federation, which includes 19 municipalities, including 18 rural settlements. According to the Federal State Statistics Service of Russia data, as of January 1, 2020, the population of the region under study was 50,127 people, of whom 35,801 were women, of which 11,621 were women of economically active (working) age.

To determine the incidence of cystitis among the adult female population of the district, we conducted a screening questionnaire survey of women who applied to the general practitioners of the Bobrovskaiy regional hospital with complaints not related to urological diseases, using the created questionnaire (Figure 1):
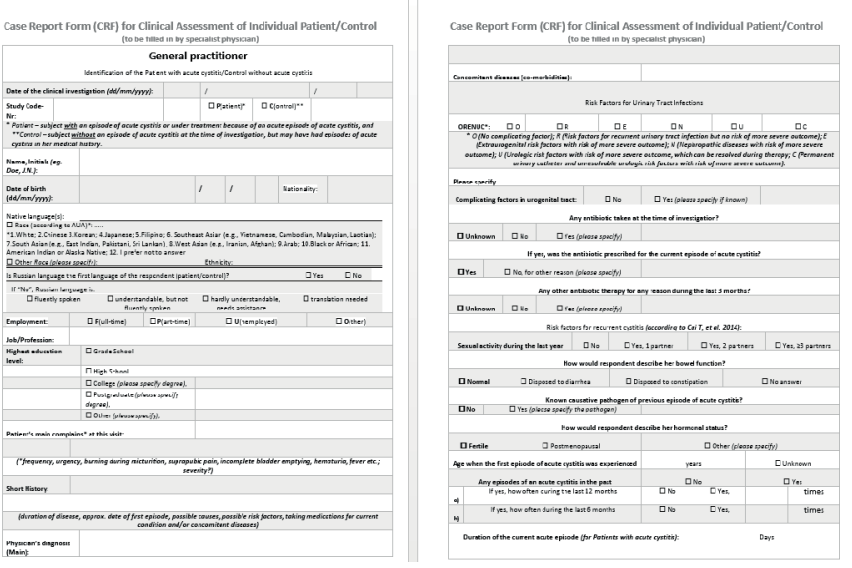

Figure 1. Questionnaire - questionnaire for the detection of recurrent cystitis

The criteria evaluated were:

- $\quad$ Age

- Profession: employed/not employed

- Education: primary, secondary, higher

- The main diagnosis with which the patients consulted a primary care specialist

- Concomitant disease

- Number of sexual partners during the year: none, 1 partner, 2 partners or more

- Hormonal status: fertile, postmenopausal

- Conducting antibiotic therapy at the time of the study and for the last 3 months

- Duration of the last acute cystitis episode (in days)

- Number of episodes of cystitis in history: for the last 12 months or for the last 6 months

\section{- the ORENUC classification system}

The classification system of the European Urological Association ORENUC, based on the clinical picture of UTI, anatomical level of UTI, severity of infection, classification of risk factors and availability of appropriate antimicrobial therapy, was used to determine the most common causes of urinary tract infections [20].

$\mathrm{O}$ - absence of complicating factors (there is no known risk factor, in all respects healthy premenopausal women)

$\mathrm{R}$ - presence of a risk factor for recurrence of urinary tract infection, but without risk factors for a serious outcome (endocrine pathological conditions, active sexual relations, hormonal imbalance, poor hygiene, etc.)

E -extraurogenital risk factor with the risk of major complications (preterm birth, pregnancy, poorly controlled diabetes mellitus, immunosuppression)

$\mathrm{N}$-nephropathic diseases with a risk of complications (renal failure, polycystic kidney disease, interstitial nephritis)

$\mathrm{U}$-urological risk factors that can be controlled by any therapy 
(ureteral obstruction due to calculus, well-controlled neurogenic urinary disorders, transient short bladder catheterization, asymptomatic bacteriuria)

C -the presence of urinary catheters and drains (stents, catheters, cystostomy, nephrostomy, etc.) or urological risk factors which cannot be controlled.

All women interviewed were divided into 3 groups:

- A total of 1014 women were interviewed (Group 1), average age $46.9 \pm 5.8$ years of which

- Group No 2 - women of reproductive age (18 to 50 years old) $(n=551)$, mean age $36.2 \pm 6.1$ years

- Group No 3 - postmenopausal women (50 to 80 years old) $(n=463)$, mean age $56.1 \pm 5.1$ years.

Statistical calculations were carried out using the computer program Statistics 10.0. $\chi^{2}$ was used as a statistical tool. Risk factors for cystitis were assessed using a one-way univariate analysis.

\section{Results}

\section{The study group}

The study included the results of a questionnaire survey of 1014 women (Group 1), whose average age was 46.9 years (min 18 years, max 80 years). It should be noted that the largest number of studied women was from group 1 were aged 51 to 60 years $(n=229)$, in group 2 from 41 to 50 years $(n=188)$ and in group 3 from 51 to 60 years old $(\mathrm{n}=205)$ (Figure 2).

All surveyed women belonged to the Caucasian race, of whom $46.1 \%(n=467)$ worked for various organizations in the region, while $53.9 \%(n=547)$ did not work for different reasons.

All respondents were included in the study after visits to primary care specialists for reasons not related to urological diseases. The most common complaints were: headaches $(n=140)$, increased blood pressure $(n=99)$, weakness $(n=48)$, sore throat $(n=33)$, back pain $(n=34)$, abdominal pain $(n=14)$, chest pain $(n=9)$, heart failure $(n=8)$, etc. 26 women (5\%), along with the main complaints that brought them to the general practitioner, noted urinary disorders, while 13 patients complained of frequent, painful urination (Figure 3).

The diagnosis that was given to the patients at the clinic were as follows: acute respiratory viral infection (ARVI), chronic cholecystitis, osteochondrosis, gastroenteritis, vegetative -vascular dystonia, cervical erosion, etc.

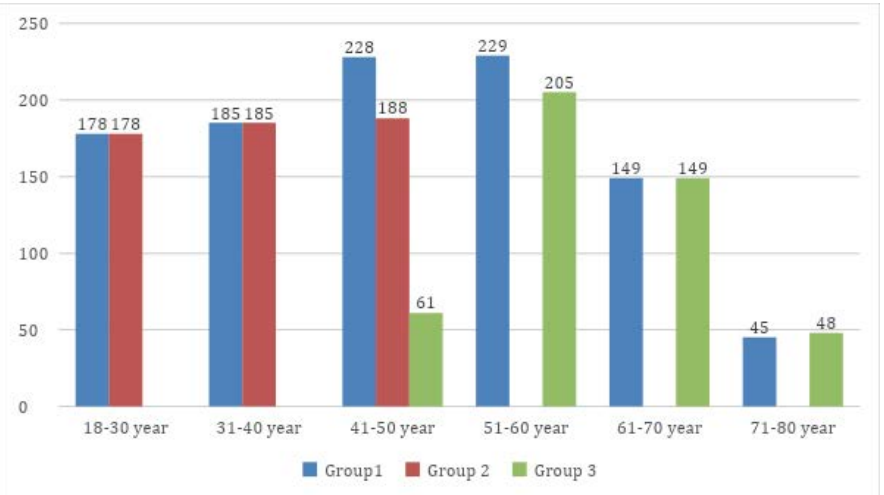

Figure 2. Age groups of the studied women

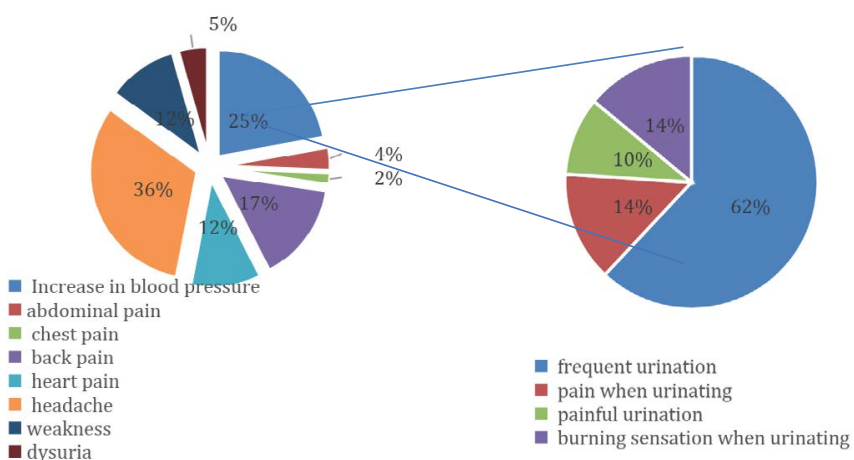

Figure 3. The most frequent reasons for going to primary care specialists of the studied women

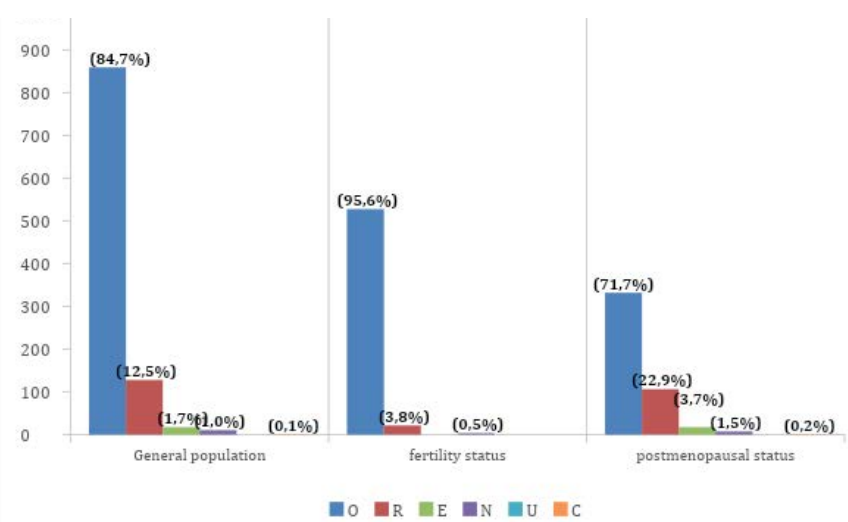

Figure 4. UTI risk Factors according to the ORENUC classification in the study group of women

\section{History of UTI}

Of the 1014 women studied, the presence of at least one episode of cystitis in the history anamnesis was noted by $17.4 \%$ of patients $(n=177)$. The largest number was found in Group 3 (postmenopausal age) - 20.6\% $(n=95)$, while in Group 2 (fertile age) - 14.9\% ( $n=82)$. Comparative analysis did not reveal a significant statistical difference $(\mathrm{p}>0.05)$.

Over the past 12 months, the presence of cystitis was noted by 32 (3.3\%) patients from Group 1; 15 (2.7\%) from Group 2 (fertile age) and 17 (3.7\%) from Group 3 (postmenopausal age). Comparative analysis between fertile and postmenopausal age groups did not reveal a significant statistical difference ( $p>0.05$ ). In this case, recurrent cystitis ( 3 or more episodes of cystitis in the last 12 months, 2 or more episodes in 6 months) $[21,22]$ in group 1 was detected in only $7(0.7 \%)$ patients. In the group of fertile and postmenopausal age, recurrent cystitis was detected in 3 and 4 patients, respectively.

\section{Risk factors of UTI}

Along with the questionnaire, the risk factors for urinary tract infection (UTI) were identified using the ORENUC classification. According to the ORENUC classification were identified in 155 patients ( $15.3 \%$ of the total number of women surveyed) (Table 1, Figure 4 ), the absence of relapse factors was recorded in 859 patients.

- $\quad$ "O" - 859 women

- $\quad$ "R" - 127 women (12.5\% of all women surveyed (group № 1); $80.2 \%$ of all risk factors for recurrent urinary tract infection) 


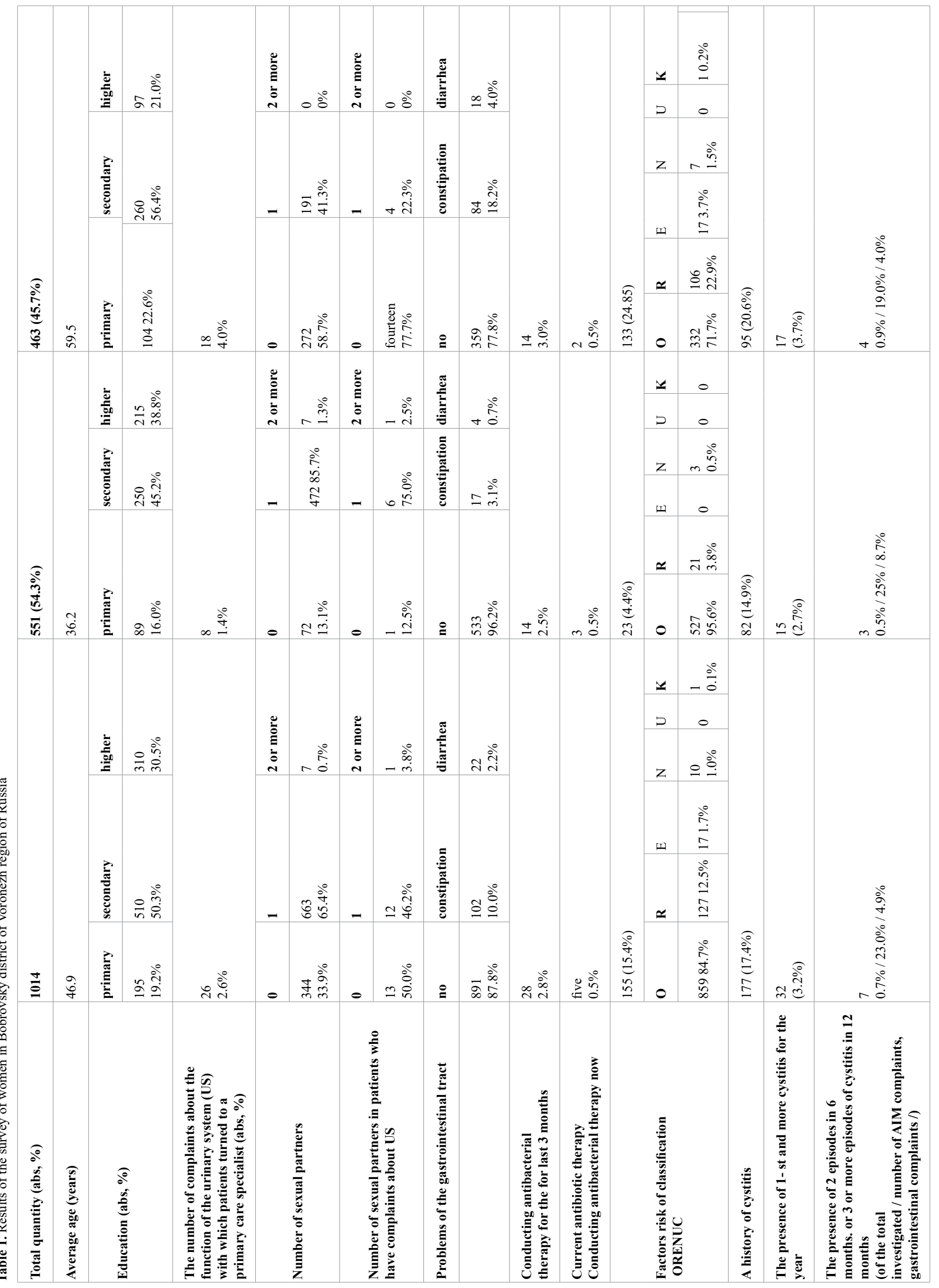


- “E” - 17 women (1.7\% of all surveyed women (group № 1), $10.9 \%$ of all risk factors)

- $\quad$ "N" - 10 women (1.0\% of all surveyed women (group № 1), 5.8\% of all risk factors)

- "C" - 1 woman (0.1\% of all surveyed women (group № 1$), 0.5 \%$ of all risk factors)

The largest number of risk factors was observed in patients of the postmenopausal age group $(\mathrm{n}=131 ; 28.3 \%)$, while in patients of group No. 2 (fertile age) they were found in 24 cases (4.3\%). At the same time, a comparative single-variant analysis revealed a statistically significant difference between these groups $(\mathrm{p}<0.05)$.

\section{Correlation of UTI risk factors and history of UTI}

In order to identify the factors contributing to the development of cystitis, a univariate comparative analysis of data from 177 patients was carried out who had at least one episode of cystitis in their history and patients who did not have cystitis $(\mathrm{n}=837)$.

The following criteria were evaluated:

- conducting antibiotic therapy at the present time and over the past 3 months

- number of sexual partners in the last year: $0,1,2$ or more

- the presence of disorders of the gastrointestinal tract: a tendency to constipation and a tendency to chronic diarrhea
- Presence of risk factors according to the ORENUC classification

These parameters were analyzed both in the general group of women (group 1), and separately in groups 2 and 3. Over the past 3 months, out of 177 patients, only 7 received antibiotic therapy. A comparative analysis between patients with and without cystitis who received antibiotic therapy did not reveal a statistically significant difference $(\mathrm{p}>0.05)$.

Lack of sexual activity in the general group of women (group 1) and group 2 does not affect the presence of cystitis in the history. The presence of one sexual partner in all groups also had no effect on the presence of cystitis in the history ( $\mathrm{p}>0.05)$.

In all groups, it was found that a history of cystitis might be associated with dysfunction of the gastrointestinal tract $(\mathrm{p}<0.05)$. At the same time, the presence of cystitis and dysfunction of the gastrointestinal tract are more typical for postmenopausal patients $(\mathrm{p}<0.05)$.

Among the risk factors for the development of urinary tract infection according to the ORENUC classification, a significant difference between the groups of patients with cystitis and without was found in groups 1 and 3 only according to the "R" factor - the presence of a risk factor for recurrent urinary tract infection, but without risk factors for serious outcome. The data is presented in the Table 2.

Table 2. Results of a comparative analysis of groups with and without cystitis in history

\begin{tabular}{|c|c|c|c|c|c|c|c|c|c|}
\hline \multirow[t]{2}{*}{ Risk factors } & \multicolumn{3}{|c|}{$\begin{array}{l}\text { Group No. } 1 \\
(n=1014)\end{array}$} & \multicolumn{3}{|c|}{$\begin{array}{l}\text { Group No. } 2 \\
\text { (Fertile age) } \\
\text { Group 2 (fertile age) } \\
(\mathrm{n}=551)\end{array}$} & \multicolumn{3}{|c|}{$\begin{array}{c}\text { Group number } 3 \text { (postmenopausal age) } \\
\text { Group } 3 \text { (postmenopausal age) } \\
(\mathrm{n}=463)\end{array}$} \\
\hline & $\begin{array}{l}\text { Cystitis "+" } \\
(\mathrm{n}=177)\end{array}$ & $\begin{array}{l}\text { Cystitis } \\
\text { "-" } \\
(n=837)\end{array}$ & $p$ & $\begin{array}{c}\text { Cystitis } \\
"+" \\
(n=82)\end{array}$ & $\begin{array}{l}\text { Cystitis } \\
"-" \\
(n=469)\end{array}$ & $p$ & $\begin{array}{c}\text { Cystitis } \\
"+" \\
(n=95)\end{array}$ & $\begin{array}{l}\text { Cystitis } \\
\text { "-" } \\
(\mathrm{n}=368)\end{array}$ & $p$ \\
\hline $\begin{array}{l}\text { Antibacterial therapy for the past } 3 \\
\text { months }\end{array}$ & $\begin{array}{c}7 \\
(4.0 \%)\end{array}$ & $\begin{array}{c}21 \\
(2.5 \%)\end{array}$ & 0.29 & $2(2.4 \%)$ & $\begin{array}{c}12 \\
(2.6 \%)\end{array}$ & 0.95 & $\begin{array}{c}5 \\
(5.3 \%)\end{array}$ & $\begin{array}{c}\text { nine } \\
(2.4 \%)\end{array}$ & 0.15 \\
\hline Lack of sexual life & $\begin{array}{c}60 \\
(33.9 \%)\end{array}$ & $\begin{array}{c}284 \\
33.9 \%\end{array}$ & 0.99 & $\begin{array}{c}7 \\
(8.5 \%)\end{array}$ & $\begin{array}{c}65 \\
(13.9 \%)\end{array}$ & 0.19 & $\begin{array}{c}53 \\
(55.8 \%)\end{array}$ & $\begin{array}{c}219 \\
(59.5 \%)\end{array}$ & 0.51 \\
\hline The presence of sexual activity & $\begin{array}{c}117 \\
(66.1)\end{array}$ & $\begin{array}{c}553 \\
(66.1)\end{array}$ & 0.99 & $\begin{array}{c}75 \\
(91.5 \%)\end{array}$ & $\begin{array}{c}404 \\
(86.1)\end{array}$ & 0.19 & $\begin{array}{c}42 \\
(44.2 \%)\end{array}$ & $\begin{array}{c}149 \\
(40.5 \%)\end{array}$ & 0.51 \\
\hline The presence of 1 sexual partner & $\begin{array}{c}117 \\
(66.1)\end{array}$ & $\begin{array}{c}546 \\
(65.3 \%)\end{array}$ & 0.83 & $\begin{array}{c}75 \\
(91.5 \%)\end{array}$ & $\begin{array}{c}397 \\
(84.6 \%)\end{array}$ & 0.10 & $\begin{array}{c}42 \\
(44.2 \%)\end{array}$ & $\begin{array}{c}149 \\
(40.5 \%)\end{array}$ & 0.51 \\
\hline Having more than 2 sexual partners & $\begin{array}{c}0 \\
(0 \%)\end{array}$ & $\begin{array}{c}7 \\
(0.8 \%)\end{array}$ & 0.22 & $\begin{array}{c}0 \\
(0 \%)\end{array}$ & $\begin{array}{c}7 \\
(1.5 \%)\end{array}$ & 0.27 & 0 & 0 & - \\
\hline Problems with the digestive tract & $\begin{array}{c}42 \\
(23.7 \%)\end{array}$ & $\begin{array}{c}82 \\
(9.8)\end{array}$ & $<0.05$ & $\begin{array}{c}9 \\
(11.0 \%)\end{array}$ & $\begin{array}{c}13 \\
(2.8 \%)\end{array}$ & $<0.05$ & $\begin{array}{c}33 \\
(34.7)\end{array}$ & $\begin{array}{c}69 \\
(18.9 \%)\end{array}$ & $<0.05$ \\
\hline Chronic constipation & $\begin{array}{c}31 \\
(17.5 \%)\end{array}$ & $\begin{array}{c}72 \\
(8.6 \%)\end{array}$ & $<0.05$ & $\begin{array}{c}7 \\
(8.5 \%)\end{array}$ & $\begin{array}{l}\text { ten } \\
(2.1 \%)\end{array}$ & $<0.05$ & $\begin{array}{c}24 \\
(25.3 \%)\end{array}$ & $\begin{array}{c}62 \\
(16.9 \%)\end{array}$ & $<0.05$ \\
\hline Chronic diarrhea & $\begin{array}{c}11 \\
(6.2 \%)\end{array}$ & $\begin{array}{c}\text { ten } \\
(1.2 \%)\end{array}$ & $<0.05$ & $\begin{array}{c}2 \\
(2.4 \%)\end{array}$ & $\begin{array}{c}3 \\
(0.6 \%)\end{array}$ & 0.12 & $\begin{array}{c}9 \\
(9.5 \%)\end{array}$ & $\begin{array}{c}7 \\
(1.9 \%)\end{array}$ & $<0.05$ \\
\hline $\begin{array}{l}\text { Risk factor of classification ORENUC } \\
\text { "O" }\end{array}$ & $\begin{array}{c}121 \\
(68.4 \%)\end{array}$ & $\begin{array}{c}738 \\
(88.2 \%)\end{array}$ & $<0.05$ & $\begin{array}{c}79 \\
(96.3 \%)\end{array}$ & $\begin{array}{c}448 \\
(95.5 \%)\end{array}$ & 0.74 & $\begin{array}{c}42 \\
(44.2 \%)\end{array}$ & $\begin{array}{c}290 \\
(78.8 \%)\end{array}$ & $<0.05$ \\
\hline $\begin{array}{l}\text { Risk factor of classification ORENUC } \\
\text { "R" }\end{array}$ & $\begin{array}{c}50 \\
(28.2 \%)\end{array}$ & $\begin{array}{c}77 \\
(9.2 \%)\end{array}$ & $<0.05$ & $3(3.7 \%)$ & $\begin{array}{c}18 \\
(3.8 \%)\end{array}$ & 0.94 & $\begin{array}{c}47 \\
(49.5 \%)\end{array}$ & $\begin{array}{c}59 \\
(16.0 \%)\end{array}$ & $<0.05$ \\
\hline $\begin{array}{l}\text { Risk factor of classification ORENUC } \\
\text { "E" }\end{array}$ & $\begin{array}{c}3 \\
(1.7 \%)\end{array}$ & $\begin{array}{c}\text { fourteen } \\
(1.7 \%)\end{array}$ & 0.98 & 0 & 0 & & $\begin{array}{c}3 \\
(3.2 \%)\end{array}$ & $\begin{array}{c}\text { fourteen } \\
(3.8 \%)\end{array}$ & 0.77 \\
\hline $\begin{array}{l}\text { Risk factor of classification ORENUC } \\
\text { "N" }\end{array}$ & $\begin{array}{c}3 \\
(1.7 \%)\end{array}$ & $\begin{array}{c}7 \\
(0.8 \%)\end{array}$ & 0.29 & 0 & $\begin{array}{c}3 \\
(0.6)\end{array}$ & 0.47 & $\begin{array}{c}3 \\
(3.2 \%)\end{array}$ & $\begin{array}{c}4 \\
(1.1 \%)\end{array}$ & 0.14 \\
\hline $\begin{array}{l}\text { Risk factor of classification ORENUC } \\
\text { "U" }\end{array}$ & 0 & 0 & - & 0 & 0 & - & 0 & 0 & - \\
\hline $\begin{array}{l}\text { Risk factor of classification ORENUC } \\
\text { "C" }\end{array}$ & 0 & $\begin{array}{c}1 \\
0.6 \%\end{array}$ & 0.65 & 0 & 0 & - & 0 & $\begin{array}{c}1 \\
(0.3 \%)\end{array}$ & 0.61 \\
\hline
\end{tabular}


Table 3. The number of registered cases of cystitis in Bobrovsky regional hospital in 20182019

\begin{tabular}{|l|c|c|}
\hline \multirow{2}{*}{ Years } & \multicolumn{2}{|c|}{ Number of reported cases of cystitis } \\
\cline { 2 - 3 } & For the first time in my life & Total \\
\hline $\mathbf{2 0 1 7}$ & 66 & 96 \\
\hline $\mathbf{2 0 1 8}$ & 29 & 76 \\
\hline $\mathbf{2 0 1 9}$ & 47 & 78 \\
\hline
\end{tabular}

\section{Discussion}

In our study, we did not find a large number of cases of recurrent UTI, in contrast to previously published works, which cited figures from $10-30 \%$ of the number of women who had one episode of cystitis $[16,17]$. This may be due to the design of the study, in which we included patients who did not initially complain of dysfunction of the urinary system, and the reason for their visit to primary care specialists was not urological diseases. Thanks to the survey, using the principle of active detection, we were able to find out that along with complaints of functional disorders of other organs and systems, these patients had functional disorders of the urinary system, as well as a history of cystitis.

Annually the statistical service of Bobrovsky regional hospital registers from 76 to 96 patients with cystitis (Table 3).

Based on the number of women living in the Bobrovsky district $(\mathrm{n}=35580)$, it was found that about $0.3 \%$ of women seek medical help with cystitis every year. In our study, we found that 32 patients (3.2\%) had at least one episode of cystitis in 12 months, of which 25 had only one episode per year. Thus, an active survey can increase the detection rate of cystitis by 10 times.

According to our data, the absence of sexual intercourse or the presence of one sexual partner during the year is not associated with the development of recurrent cystitis.

We have found a relationship between the development of cystitis and impaired gastrointestinal function almost equally associated with both a tendency to constipation and chronic diarrhea.

The current study excluded by purpose patients who visited their physicians because of urogenital complains in order to investigate the epidemiology of UTI in the general population and not in a selected population with obvious complaints caused by urogenital infections and/or inflammations.

\section{Conclusion}

This study confirmed previously published works on risk factors for the development of cystitis. In addition, we found that the prevalence of cystitis is about $3.2 \%$, whereas women seek medical help 10 times less, which indicates the need to strengthen health education among the population to inform about the risk factors for the development of cystitis and the possibility of its prevention.

\section{References}

1. Griebling TL (2005) Urologic diseases in America project: trends in resource use for urinary tract infections in women. J Urol 173: 1281-1287. [Crossref]

2. Foxman B (2014) Urinary tract infection syndromes: occurrence, recurrence, bacteriology, risk factors, and disease burden. Infect Dis Clin North Am 28: 1-13. [Crossref]

3. Renard J, Ballarini S, Mascarenhas T, Zahran M, Quimper E, et al. (2014) Recurrent Lower Urinary Tract Infections Have a Detrimental Effect on Patient Quality of Life: a Prospective, Observational Study. Infect Dis Ther 4: 125-135. [Crossref]

4. Wagenlehner F, Wullt B, Ballarini S, Zingg D, Naber KG (2018) Social and economic burden of recurrent urinary tract infections and quality of life: a patient web-based study (GESPRIT). Expert Rev Pharmacoecon Outcomes Res 18: 107-117. [Crossref]

5. Aydin A, Ahmed K, Zaman I, Khan MS, Dasgupta P (2015) Recurrent urinary tract infections in women. Int Urogynecol J 26: 795-804. [Crossref]

6. Foxman B, Frerichs RR (1985) Epidemiology of urinary tract infection: I. Diaphragm use and sexual intercourse. Am J Public Health 75: 1308-1313. [Crossref]

7. Foxman B (1990) Recurring urinary tract infection: incidence and risk factors. $\mathrm{Am} J$ Public Health 80: 331-333. [Crossref]

8. Foxman B (2003) Epidemiology of urinary tract infections: incidence, morbidity, and economic costs. Dis Mon 49: 53-70. [Crossref]

9. Scriabin NG, Alexandrov VP, Korenkov DG, Nazarov TN (2006) Cystitis. Publishing house of St. Petersburg BMAPO, 2006: 146c.

10. Kurnosova NV (2011) Optimization of therapeutic and diagnostic tactics in women with chronic recurrent bacterial cystitis. Abstract of the candidate's dissertation, Saratov 22.

11. Laurent O.B., Sinyakova L.A., Kosova I.V. (2008) Recurrent urinary tract infections. Algorithm for diagnosis and treatment. Manual for doctors - M., Medical news agency. pp: 32 .

12. G. Boncat, Bartoletti R, Bruyere F, Cai T, Geerlings S, et al. (2020) EAU Guidelines on Urological Infections.

13. Scholes D, Hooton TM, Roberts PL, Stapleton AE, Gupta K, et al. (2000) Risk factors for recurrent urinary tract infection in young women. J Infect Dis 182: 1177-1182. [Crossref]

14. Hawn TR, Scholes D, Li SS, Wang H, Yang Y, et al. (2009) Toll-like receptor polymorphisms and susceptibility to urinary tract infections in adult women. PLoS One 4: e5990. [Crossref]

15. Cai T, Mazzoli S, Mondaini N, Meacci F, Nesi G, et al. (2012) The role of asymptomatic bacteriuria in young women with recurrent urinary tract infections: to treat or not to treat? Clin Infect Dis 55: 771-777. [Crossref]

16. Cai T, Mazzoli S, Migno S, Malossini G, Lanzafame P, et al. (2014) Development and validation of a nomogram predicting recurrence risk in women with symptomatic urinary tract infection. Int J Urol 21: 929-934. [Crossref]

17. Apolikhin OI, Sivkov AV, Chernyshev IV, Zolotukhin OV, Shchukin AV, et al. (2012) Program " Urology " modernization of health care on the example of the urological service of the Voronezh region. Exp clin urol: 4-8.

18. Shishkin SV, Apolikhin OI, Sazhina SV, Shaderkin IA, Zolotukhin OV, et al. (2015) Improving the effectiveness of specialized medical care: the experience of structural transformations. Issues State Municipal Management 2: 79-99.

19. Apolikhin OI, Sivkov AV, Shishkin SV, Sheiman IM, Son IM, et al. (2014) Medical and economic aspects of a comprehensive staged standardized program for the diagnosis and treatment of benign prostatic hyperplasia. Exp Clin Urol 3: 4-8

20. Johansen TE, Botto H, Cek M, Grabe M, Tenke P, et al. (2011) Critical review of curren definitions of urinary tract infections and proposal of an EAU/ESIU classification system. Int J Antimicrob Agents 38: S64-S70. [Crossref]

21. Perepanova TS, Kozlov RS, Rudnov VA, Sinyakova LA, Palagin IS (2020) Antimicrobial therapy and prevention of infections of the kidneys, urinary tract and male genital organs. Federal clinical guidelines, M. Uromedia.

22. Clinical guidelines of the Ministry of Health of the Russian Federation "Bacterial cystitis in adults". Available at: https://www.ooorou.ru/public/uploads/ROU/Files.

Copyright: @2021 Apolikhin OI. This is an open-access article distributed under the terms of the Creative Commons Attribution License, which permits unrestricted use, distribution, and reproduction in any medium, provided the original author and source are credited. 